\title{
Decreased Bioactivity of the Guanine Nucleotide-binding Protein That Stimulates Adenylate Cyclase in Hearts from Cardiomyopathic Syrian Hamsters
}

Paul D. Kessler, Andree E. Cates, Cornelis Van Dop, ${ }^{\star}$ and Arthur M. Feldman

Department of Medicine, The Johns Hopkins University School of Medicine, Baltimore, Maryland 21205; and *The Howard Hughes

Medical Institute at Children's Hospital and Harvard Medical School, Boston, Massachusetts 02115

\begin{abstract}
We investigated regulation of cardiac adenylate cyclase in 29-d-old BIO 14.6 Syrian hamsters, which inherit cardiomyopathy as an autosomal recessive trait. Pharmacologic stimulation of adenylate cyclase in cardiac membranes with isoproterenol, fluoride ion, guanine nucleotide, forskolin, and manganous ion indicated that there was defective coupling of the guanine nucleotide-binding protein that stimulates adenylate cyclase $\left(G_{8}\right)$ to adenylate cyclase. $\mathrm{Cyc}^{-}$complementation assays revealed $\simeq \mathbf{5 0 \%}$ less $\mathbf{G}_{\mathbf{8}}$ activity in cardiac and skeletal muscle from cardiomyopathic hamsters. Despite this decrease in functional $G_{8}$, there were no changes in immunologic levels of the alpha-subunit of $G_{s}\left(\alpha G_{s}\right)$ or in levels of mRNA encoding $\alpha G_{8}$. The defect in $G_{8}$ bioactivity was limited to cardiac and skeletal muscle, occurred only in animals homozygous for the dystrophic trait, and was demonstrable before any cardiac abnormalities were evident on light microscopy. By contrast, cardiac levels of $\boldsymbol{\beta}$-adrenergic receptors were not different in cardiac membranes from BIO 14.6 hamsters. We conclude that a functional defect in $\alpha G_{\mathbf{g}}$ may contribute to the contractile abnormalities in the cardiomyopathic BIO 14.6 hamster. However, the etiology of the $\alpha G_{8}$ defect remains obscure.
\end{abstract}

\section{Introduction}

Membrane transduction for a large number of extracellular signals in eukaryotic cells is mediated by a family of homologous guanine nucleotide-binding regulatory proteins ( $G$ proteins) $)^{1}(1,2)$. In the heart, the heterotrimeric $G$ proteins couple extracellular receptors with stimulation $\left(G_{s}\right)$ or inhibition $\left(G_{i}\right)$, respectively, of the effector enzyme adenylate cyclase, the primary regulator of intracellular concentrations of the second messenger cAMP. Since cyclic AMP modulates cardiac contractility $(3,4)$, alterations in any of the components of the

Address reprint requests to Dr. Feldman, Division of Cardiology, Hunterian 405, The Johns Hopkins Hospital, 725 North Wolfe Street, Baltimore, MD 21205.

Received for publication 25 October 1988 and in revised form 30 January 1989.

1. Abbreviations used in this paper: $\mathrm{G}$ protein, guanine nucleotidebinding regulatory protein; $G_{i}$ and $G_{s}, G$ proteins that respectively inhibit or stimulate the effector enzyme adenylate cyclase; $\alpha G_{i}$ and $\alpha G_{s}$, alpha-subunits of $G_{i}$ and $G_{s} ; G p p(N H) p$, guanylyl-imidodiphosphate; ICYP, iodocyanopindolol; PVDF, polyvinylidene difluoride.

J. Clin. Invest.

(C) The American Society for Clinical Investigation, Inc.

0021-9738/89/07/0244/09 \$2.00

Volume 84, July 1989, 244-252 receptor-adenylate cyclase transmembrane signaling complex could significantly alter myocardial function.

Recent studies have demonstrated substantial changes in $\mathbf{G}$ protein function in failing human and animal hearts. In the human heart, end-stage idiopathic congestive failure is associated with decreased $\beta$-adrenergic receptors and increased activity of $\mathrm{G}_{\mathrm{i}}(5)$. In contrast, heart failure due to left ventricular pressure overload in the dog is associated with increased $\beta$ adrenergic receptors and decreased activity of $G_{s}(6)$. Both of these studies were limited by the fact that tissue was obtained at the end stage of the disease process. In order to further evaluate the role of receptor-adenylate cyclase coupling by $G$ proteins in failing heart, we evaluated $G$ protein activity in a genetic animal model of cardiac failure, the myopathic Syrian hamster.

The cardiomyopathic hamster in both cardiac and skeletal muscle develops a well-described series of pathologic changes which are inherited as an autosomal recessive trait $(7,8)$. In the heart, myolysis occurring at $\simeq \mathbf{4 0} \mathrm{d}$ of age is followed by hypertrophy and ventricular dilatation with eventual frank congestive heart failure and death. Although numerous biochemical abnormalities have been described in both young and old myopathic hamsters $(9-11)$, the primary alteration responsible for the muscle disease remains obscure. In this study, we demonstrate muscle-specific alterations in $\mathbf{G}_{\mathbf{s}}$ function that occur before the onset of pathologic changes in young myopathic hamsters and may contribute to the development of the disease state.

\section{Methods}

Materials. Polyethylene lauryl ether (Lubrol PX) was obtained from Pierce Chemical Co. (Rockford, IL); NAD and guanylyl-imidodiphosphate [Gpp(NH)p] from Boehringer-Mannheim (Mannheim, Federal Republic of Germany); pertussis toxin from List Biologicals (Campbell, CA); cholera toxin and Nonidet P-40 from Sigma Chemical Co. (St. Louis, MO); sucrose from Schwartz-Mann (Cleveland, $\mathrm{OH}$ ); Immobilon polyvinylidene difluoride (PVDF), transfer membranes from Millipore Corp. (Bedford, MA); $\left[\alpha-{ }^{32}\right.$ P]ATP from ICN Radiochemicals (Irvine, CA); $\left[\alpha-{ }^{32} \mathrm{P}\right] \mathrm{dCTP},{ }^{125} \mathrm{I}$-iodocyanopindolol (ICYP), [ $\left.{ }^{32} \mathrm{P}\right] N A D$, and ${ }^{125} \mathrm{I}-\mathrm{F}\left(\mathrm{ab}^{\prime}\right)_{2}$ fragment of rabbit anti-goat IgG from DuPont Co. (Wilmington, DE); culture media from Gibco Laboratories (Grand Island, NY) or Whittaker Bioproducts (Walkerville, MD); and all other reagents were the highest grade commercially available.

Rabbit antisera (A-584) raised to a synthetic peptide identical to unique amino acid sequences of the carboxyl-terminal amino acids of the alpha-subunit of bovine $\mathrm{G}_{\mathrm{s}}\left(\alpha \mathrm{G}_{\mathrm{s}}\right)$, which had been deduced from a cDNA clone was the generous gift of Dr. J. D. Robishaw (Geisinger Clinic, Danville, PA). Affinity-purified rabbit antisera $\left(G_{12}\right)$ raised to a synthetic peptide corresponding to amino acids 306-319 (SKFEDLNKRKDTKE) of mouse $\alpha \mathrm{G}_{\mathrm{i}}(12)$ were generously provided by Dr. Henry R. Bourne (University of California, San Francisco, CA). $A$ partially purified $G$ protein preparation from bovine brain was the generous gift of Dr. Richard R. Neubig (University of Michigan, Ann Arbor, MI). A cDNA clone encoding the $\alpha$-subunit of rat $\mathrm{G}_{\mathrm{s}}(13)$, was 
generously provided by Dr. R. R. Reed (Johns Hopkins University School of Medicine, Baltimore, MD).

Animals. Three genetically defined strains of male golden Syrian hamsters (Mesocricetus auratus) were obtained from Bio Breeders (Fitchburg, MA): (a) cardiomyopathic animals (BIO 14.6), (b) animals without propensity for cardiomyopathy $\left(\mathrm{F}_{1}\right.$ hybrid of strains BIO 1.5 and BIO 87.20, designated $F_{1} B$ ), and $(c) F_{1}$ hybrids of BIO 14.6 and BIO 87.20 (designated $F_{1} M$ ). The animals were fed ad libitum on a diet containing adequate trace elements, vitamin $\mathrm{E}$, thiamine, and other nutrients for which deficiency is known to cause cardiomyopathy in animals (14). After deep anesthesia was induced with intraperitoneal pentobarbital $(60 \mathrm{mg} / \mathrm{kg})$, venous blood was collected and organs were excised. Hearts were placed in cold buffer: $20 \mathrm{mM}$ Tris- $\mathrm{Cl}$ (pH 7.5), $150 \mathrm{mM} \mathrm{NaCl}$. Brain, liver, and hind limb muscle were rapidly frozen in liquid nitrogen and stored at $-70^{\circ} \mathrm{C}$ before preparation of membranes.

Preparation of membranes. Cardiac ventricular tissue was isolated, stripped of adipose tissue, weighed, and minced with scissors. Tissue from the hearts of two hamsters was homogenized (Polytron, Brinkmann Instruments Co., Inc., Westbury, NY) for $<5 \mathrm{~s}$ in $5 \mathrm{mM}$ Tris-Cl (pH 7.5), $250 \mathrm{mM}$ sucrose, $1 \mathrm{mM}$ EGTA buffer, and centrifuged for 20 min at $1,100 \mathrm{~g}\left(4^{\circ} \mathrm{C}\right)$. The resulting pellet was washed twice and resuspended with a Potter-Elvejehm homogenizer. The final particulate fraction was filtered through gauze, aliquoted, and stored at $-70^{\circ} \mathrm{C}$. Storage for up to $6 \mathrm{mo}$ had no effect on adenylate cyclase or $\mathrm{G}$ protein activity. Tissue from hind limb muscles were prepared in a similar manner. Proteins were measured (15) using bovine serum albumin as standard. Membranes deficient in contractile proteins were prepared for receptor antagonist binding experiments (16). Tissue was disrupted with a Polytron in $10 \mathrm{mM}$ Tris-Cl buffer ( $\mathrm{pH} 7.8$ ) containing $1 \mathrm{mM}$ EGTA. The homogenate was added to an equal volume of $1 \mathrm{M} \mathrm{KCl}$, stirred for $15 \mathrm{~min}$ in the cold, and centrifuged at $49,000 \mathrm{~g}$ for $15 \mathrm{~min}$ $\left(4^{\circ} \mathrm{C}\right)$. The resulting pellet was resuspended in $75 \mathrm{mM}$ Tris- $\mathrm{Cl}$ buffer (pH 7.5) with $10 \mathrm{mM} \mathrm{MgCl}$ and centrifuged again. The final pellet was resuspended in buffer containing $50 \mathrm{mM}$ Tris- $\mathrm{Cl}$ (pH 7.4), $250 \mathrm{mM}$ sucrose, $1 \mathrm{mM}$ EGTA buffer, and stored at $-70^{\circ} \mathrm{C}$.

Erythrocyte membranes were prepared from human or hamster blood after lysing cells in $5 \mathrm{mM} \mathrm{Na}-\mathrm{PO}_{4}(\mathrm{pH} 8)$ (17). Membranes were prepared from whole brain as described by Worley et al. (18). Liver was homogenized in $1 \mathrm{mM} \mathrm{NaHCO}$, filtered through gauze, and centrifuged at $1,500 \mathrm{~g}$ for $10 \mathrm{~min}\left(4^{\circ} \mathrm{C}\right)$. The pellet was washed twice and resuspended in buffer containing $5 \mathrm{mM}$ Tris-Cl (pH 7.5), $250 \mathrm{mM}$ sucrose, $1 \mathrm{mM}$ EGTA, $1 \mathrm{mM} \mathrm{MgCl}$, and $1 \mathrm{mM}$ DTT.

Assay of adenylate cyclase. Adenylate cyclase was measured as described (19). In brief, cardiac membranes were incubated in a reaction mixture $(100 \mu \mathrm{l})$ containing $50 \mathrm{mM} \mathrm{Na}$-Hepes (pH 7.6), $0.5 \mathrm{mM}$ $\mathrm{MgCl}_{2}, 0.3 \mathrm{mM} \mathrm{KCl}, 0.1 \mathrm{mM}\left[\alpha-{ }^{32} \mathrm{P}\right] \mathrm{ATP}(0.1-0.2 \mathrm{mCi} / \mathrm{mmol}), 20$ $\mu \mathrm{M}$ cAMP, $1.0 \mathrm{mM}$ DTT, $1.0 \mu \mathrm{M}$ DL-propranolol, $5 \mathrm{mM}$ creatine phosphate, $2.8 \mathrm{U}$ of creatine kinase, and agonists indicated in the figure legends and tables. GTP $(10 \mu \mathrm{M})$ was added to basal and isoproterenol-stimulated reactions. The reaction mixture was prepared at $4^{\circ} \mathrm{C}$ and the reaction was carried out at $30^{\circ} \mathrm{C}$. After a 20 -min incubation period, the reaction was terminated by adding $100 \mu \mathrm{l}$ of buffer (stop buffer) containing $50 \mathrm{mM} \mathrm{Na-Hepes} \mathrm{(pH} \mathrm{7.5),} 2 \mathrm{mM} \mathrm{ATP,} 0.5$ $\mathrm{mM}\left[{ }^{3} \mathrm{H}\right] \mathrm{cAMP}(0.8 \mathrm{Ci} / \mathrm{mol})$, and $2 \%(\mathrm{wt} / \mathrm{vol})$ SDS and heating for 3 min at $90^{\circ} \mathrm{C}$. cAMP was fractionated using Dowex-alumina chromatography (20). Recovery was $70-90 \%$ and all reactions were performed in triplicate with $<10 \%$ variation.

$\mathrm{Cyc}^{-}$complementation assay. The capability of detergent extract from cardiac membranes to reconstitute $\beta$-adrenergic stimulation of adenylate cyclase in membranes of the $\mathrm{G}_{\mathrm{s}}$-deficient cyc ${ }^{-} \mathrm{S} 49$ murine lymphoma cell was measured using a modification of a previously described technique (5). Cyc ${ }^{-}$S49 lymphoma cells (strain 94.15.1) were obtained from the University of California Cell Culture Facility (San Francisco, CA) and propagated in Dulbecco's modified Eagle's medium containing $25 \mathrm{mM} \mathrm{Na-Hepes} \mathrm{(pH} \mathrm{7.4)} \mathrm{and} 10 \%$ (vol/vol) heat-inactivated horse serum (21). Plasma membranes were prepared as described (22) utilizing a nitrogen cavitation apparatus (Parr Instru- ment Co., Moline, IL) to disrupt the cells and sucrose density-gradient separation to purify the membranes. The $\mathrm{cyc}^{-}$membranes were suspended at a concentration of $\simeq 3 \mathrm{mg} / \mathrm{ml}$ in buffer containing $20 \mathrm{mM}$ Na-Hepes (pH 8.0), $2 \mathrm{mM} \mathrm{MgCl}, 1 \mathrm{mM}$ EDTA, and $1 \mathrm{mM}$ DTT, frozen, and then stored at $-70^{\circ} \mathrm{C}$.

Cardiac membranes were incubated at $37^{\circ} \mathrm{C}$ for $20 \mathrm{~min}$ and then centrifuged at $15,000 \mathrm{~g}$ for $5 \mathrm{~min}$ at room temperature. The pellet was resuspended in buffer containing $10 \mathrm{mM}$ Tris-Cl (pH 7.5), $0.2 \%$ (vol/ vol) Lubrol-PX, $0.1 \mathrm{mM}$ EDTA, $10 \mathrm{mM} \mathrm{MgCl}$, and $1 \mathrm{mM}$ DTT and agitated for $60 \mathrm{~min}$ at room temperature. The incubate was centrifuged at $15,000 \mathrm{~g}$ for $15 \mathrm{~min}$ at room temperature, and the supernatant (membrane extract) was removed and utilized for assay of $\mathrm{G}$ protein activity. Cyc ${ }^{-}$membranes (50-60 $\left.\mu \mathrm{g}\right)$ and cardiac membrane extract $(0-20 \mu \mathrm{l})$ were incubated in reaction buffer $(90 \mu \mathrm{l})$ containing $50 \mathrm{mM}$ Na-Hepes (pH 7.4), $12.5 \mathrm{mM} \mathrm{MgCl}, 0.3 \mathrm{mM} \mathrm{KCl}, 0.1 \mathrm{mM} \mathrm{ATP}, 20$ $\mu \mathrm{M}$ cAMP, $0.1 \mathrm{mM}$ DTT, $5 \mathrm{mM}$ creatine phosphate, $2.8 \mathrm{U}$ of creatine kinase, $10 \mu \mathrm{M}$ isoproterenol, and either $10 \mu \mathrm{M} \mathrm{Gpp}(\mathrm{NH}) \mathrm{p}$ or $10 \mu \mathrm{M}$ GTP $\gamma \mathrm{s}$ for $20 \mathrm{~min}\left(30^{\circ} \mathrm{C}\right)$. Forskolin $(10 \mu \mathrm{M})$ was also included in some experiments as noted. Reaction buffer $(10 \mu \mathrm{l})$ containing $\left[\alpha-{ }^{32} \mathrm{P}\right]$ ATP $(90 \mathrm{Ci} / \mathrm{mmol})$ was then added and the incubation was continued for $40 \mathrm{~min}$. The reaction was stopped by adding $100 \mu \mathrm{l}$ of stop buffer and heating to $80^{\circ} \mathrm{C}$; and cAMP accumulation was measured as described for the adenylate cyclase assay. Adenylate cyclase activity in the detergent extracts from membrane extracts was negligible; however, the activity and endogenous activity of the cyc ${ }^{-}$membranes were subtracted to calculate the increase in adenylate cyclase activity resulting from addition of $\alpha \mathrm{G}_{\mathrm{s}}$. Preliminary studies using extracts from each tissue indicated that the amount of cAMP synthesized was directly proportional to the amount of tissue extract added and that the rate of cAMP synthesis remained constant during the 40-min incubation. In order to maintain comparable concentrations of protein and detergent in these preliminary experiments, the reaction mixtures were supplemented with membrane extracts that had been heated to $90^{\circ} \mathrm{C}$ for $10 \mathrm{~min}$ to inactivate $\mathrm{G}_{\mathrm{s}}$ protein. As all complementation studies were completed using a single batch of $\mathrm{cyc}^{-}$membranes, the experimental results are expressed as picomoles cAMP produced \pm SEM.

Bacterial toxin catalyzed ADP-ribosylations. Cardiac membranes $(75 \mu \mathrm{g})$ were centrifuged at $15,000 \mathrm{~g}$ and resuspended in $100 \mu \mathrm{l}$ of a buffer containing $50 \mathrm{mM}$ Tris- $\mathrm{Cl}$ (pH 8.0), $10 \mu \mathrm{M}\left[\alpha-{ }^{32} \mathrm{P}\right] \mathrm{NAD}$ (20 $\mathrm{Ci} / \mathrm{mmol}$ ), $6 \mathrm{mM} \mathrm{MgCl}$, $10 \mathrm{mM}$ thymidine, $2 \mathrm{mM} \mathrm{GTP,} 2.5 \mathrm{mM}$ ATP, $40 \mu \mathrm{mM}$ isoniazid, and $50 \mu \mathrm{g} / \mathrm{ml}$ pertussis toxin. Before use, pertussis toxin was activated by incubation with $100 \mathrm{mM}$ DTT. The reaction mixture was incubated for $90 \mathrm{~min}$ at $30^{\circ} \mathrm{C}$. After centrifugation $(15,000 \mathrm{~g}$ for $5 \mathrm{~min}$ at room temperature), the membranes were washed with buffer containing $50 \mathrm{mM}$ Tris- $\mathrm{Cl}$ (pH 8.0), $6 \mathrm{mM} \mathrm{MgCl}_{2}$, $1 \mathrm{mM}$ EDTA, $146 \mathrm{mM}$ sucrose before suspension in electrophoresis buffer $(50 \mu \mathrm{l})$ containing $62 \mathrm{mM}$ Tris-Cl (pH 6.8), 2\% (wt/vol) SDS, $10 \%$ (wt/vol) glycerol, $0.7 \mathrm{M}$ 2-mercaptoethanol, and electrophoresed on a $7.5 \%$ gel using SDS-PAGE (23). The gel was stained with Coomassie Blue, dried on cellulose, and exposed X-OMAT AR film (Eastman Kodak Co., Rochester, NY) for $\simeq 38 \mathrm{~h}$ at $-70^{\circ} \mathrm{C}$ with an intensifying screen (Quanta III-T, DuPont Co.). The relative autoradiographic intensities for radiolabeled pertussis toxin substrates were determined using two-dimensional densitometry (Loates, Inc., Westminster, MD). The relative intensity of the $40,000-\mathrm{mol} \mathrm{wt}$ band on autoradiographs varied in different experiments as a result of variations in the film exposure time and the specific activity of the radiolabeled substrate. Therefore, we standardized autoradiographic densities obtained from separate experiments by including membranes from at least four normal hamster hearts in each experiment and expressing the levels of ADP-ribosylated proteins in membranes from cardiomyopathic hearts as a percentage of the mean of the normal controls. This method of quantifying $G$ protein levels in cardiac tissue has been used previously (5).

G protein substrates of cholera toxin were assayed in an analogous manner as described (5). Membranes $(\simeq 100 \mu \mathrm{g})$ were resuspended in $100 \mu \mathrm{l}$ of buffer containing $100 \mathrm{mM} \mathrm{K}-\mathrm{PO}_{4}(\mathrm{pH}$ 7.0), $2 \mathrm{mM} \mathrm{GTP}, 2.5$ 
mM ATP, $20 \mathrm{mM}$ thymidine, $20 \mathrm{mM}$ arginine, $10 \mathrm{U}$ aprotinin, and 10 $\mu \mathrm{M}\left[{ }^{32} \mathrm{P}\right] \mathrm{NAD}(20 \mathrm{Ci} / \mathrm{mmol})$. The cholera toxin was preactivated by incubating in $10 \mathrm{mM}$ DTT for $30 \mathrm{~min}$ at $30^{\circ} \mathrm{C}$.

Immunoblotting. Cardiac membranes $\left(50 \mu \mathrm{g}\right.$ for $\alpha \mathrm{G}_{s} ; 40 \mu \mathrm{g}$ for $\alpha \mathrm{G}_{\mathrm{i}}$ ) were centrifuged at $15,000 \mathrm{~g}$ for $4 \mathrm{~min}$, resuspended in electrophoresis buffer, resolved on a $10 \%$ gel using SDS-PAGE, and electrophoretically transferred using 3-(cyclohexylamino)-1-propanesulfonic acid (pH 11.0) in 10\% (vol/vol) methanol to Immobilon PVDF membranes for immunoblotting. After transfer, the membranes were incubated for $1 \mathrm{~h}$ at room temperature in immunoblotting buffer $(50 \mathrm{mM}$ Tris-Cl (pH 8.0), $2 \mathrm{mM} \mathrm{CaCl}_{2}, 80 \mathrm{mM} \mathrm{NaCl}, 5 \%$ (wt/vol) nonfat dry milk, and $0.02 \%$ (wt/vol) sodium azide) to which $0.2 \%$ (vol/vol) Nonidet $\mathrm{P}-40$ and $10 \%$ (vol/vol) horse serum had been added. The blots were then incubated with immunoblotting buffer containing antisera (diluted 1:1,000), 2\% Nonidet P-40, and $0.2 \%$ SDS for $2 \mathrm{~h}$ before being washed three times for 15 min with immunoblotting buffer containing $2 \%$ Nonidet P-40 and $0.2 \%$ SDS. The antigen-antibody complexes were detected by then incubating the blots with goat anti-rabbit ${ }^{125} \mathrm{I}$ $\mathrm{F}\left(\mathrm{ab}^{\prime}\right)_{2}\left(2 \times 10^{6} \mathrm{cpm} / \mathrm{ml}\right)$ for $1 \mathrm{~h}$ at room temperature. The blots were again washed as described above and washed twice (15 min) in immunoblotting buffer containing $0.2 \%$ (vol/vol) Nonidet P-40. The blots then exposed Kodak X-OMAT AR film overnight with an intensifying screen. The intensity of autoradiographic bands was measured using two-dimensional densitometry and comparisons were performed as described for analysis of ADP-ribosylations. In addition ${ }^{125} \mathrm{I}-\mathrm{F}\left(\mathrm{ab}^{\prime}\right)_{2}$ binding was quantified by excising appropriate bands from Western blots and measuring ${ }^{125}$ I using a gamma-counter (TM Analytic Inc., Elk Grove Village, IL). The two methods gave comparable results.

Preliminary experiments demonstrated complete peptide transfer from the polyacrylamide gel. Additionally, Ponceau Red staining of the PVDF membrane demonstrated comparable protein concentrations in the normal and myopathic groups. To determine that the proteins were completely bound to the PVDF membrane under our transfer conditions, a second layer of the PVDF support membrane was placed next to the primary membrane during the transfer. This second membrane showed no protein binding by Ponceau Red staining.

Northern blot and dot blot analysis of RNA. Total RNA was purified from hearts, and blots were prepared as described (24). cDNA (1.8 $\mathrm{kb})$ encoding the $\alpha$-subunit of rat $\mathrm{G}_{\mathrm{s}}$ was radiolabeled $\left(10^{9} \mathrm{cpm} / \mu \mathrm{g}\right.$ DNA) with $\left[\alpha-{ }^{32} \mathrm{P}\right] \mathrm{dCTP}$ using a random priming method (25). After prehybridization, the blots were hybridized with the radiolabeled cDNA probe $\left(10^{6} \mathrm{cpm} / \mathrm{ml}\right)$ for $48 \mathrm{~h}$ at $42^{\circ} \mathrm{C}$ before being washed and exposing Kodak X-OMAT AR film with an intensifying screen. Autoradiographic densities were quantified using two-dimensional densitometry.

$Q$ uantitation of $\beta$-adrenergic receptors. $\beta$-Adrenergic receptor density in cardiac membranes was measured using ${ }^{125} \mathrm{I}-\mathrm{ICYP}$ binding as previously described (26). Cardiac membranes $(\simeq 50 \mu \mathrm{g})$ were incubated for $2 \mathrm{~h}$ at $30^{\circ} \mathrm{C}$ with varied concentrations (3-150 pM) of ${ }^{125} \mathrm{I}$ ICYP $(2,200 \mathrm{Ci} / \mathrm{mmol})$. Specific $\beta$-adrenergic receptor binding was defined as bound ICYP displaced by $1 \mu \mathrm{M}$ DL-propranolol, and the binding parameters $B_{\max }$ and $K_{d}$ were determined by nonlinear least squares fitting utilizing a previously defined computerized algorithm (27).

Statistics. Differences between two groups were analyzed with Student's $t$ test. For comparison of three groups, a one-way analysis of variance was employed using the Bonforonni correction with $\alpha=0.05$. Values presented are means \pm SEM (28).

\section{Results}

Experimental animals. The weights of hearts from 29-d-old animals were the same in the normal animals $\left(F_{1} B\right)(286 \pm 13$ $\mathrm{mg}, n=10)$, the BIO 14.6 hamsters $(289 \pm 13 \mathrm{mg})$, and the $\mathrm{F}_{1}$ hybrid animals $(289 \pm 9 \mathrm{mg})$. In addition, microscopic exami-
Table I. Adenylate Cyclase Activity in Membranes Prepared from Hearts of Normal and Cardiomyopathic Syrian Hamsters

\begin{tabular}{lrrrc}
\hline \multicolumn{1}{c}{ Agonists } & \multicolumn{1}{c}{$\mathrm{F}_{1} \mathrm{~B}$} & \multicolumn{1}{c}{$\mathrm{F}_{1} \mathrm{M}$} & BIO 14.6 & $P$ \\
\hline \multicolumn{5}{c}{ pmol cAMP/mg protein per min } \\
$\mathrm{GTP}(10 \mu \mathrm{M})$ & $1.1 \pm 0.1$ & $1.2 \pm 0.1$ & $1.3 \pm 0.1$ & $\mathrm{NS}$ \\
$\mathrm{Mn}^{2+}(10 \mathrm{mM})$ & $2.1 \pm 0.2$ & $2.1 \pm 0.2$ & $2.8 \pm 0.2$ & $\mathrm{NS}$ \\
Fluoride $(10 \mathrm{mM})$ & $5.4 \pm 0.4$ & $4.9 \pm 0.2$ & $3.8 \pm 0.2$ & $<0.025$ \\
Forskolin $(10 \mu \mathrm{M})$ & $20.1 \pm 1.1$ & $22.7 \pm 1.7$ & $16.1 \pm 0.9$ & $<0.025$ \\
Isoproterenol & & & & \\
$\quad(100 \mu \mathrm{M})+\mathrm{GTP}$ & $3.2 \pm 0.3$ & $3.4 \pm 0.2$ & $2.2 \pm 0.5$ & $<0.01$
\end{tabular}

Adenylate cyclase activity was assayed in membranes prepared from normal $\left(F_{1} B\right)$ animals, animals heterozygous for the cardiomyopathic trait $\left(F_{1} M\right)$, and cardiomyopathic (BIO 14.6) animals in the presence of the indicated agonists. Values represent the mean $\pm \operatorname{SE}(n=5)$ and all assays were performed in triplicate. Activities in the presence of isoproterenol, fluoride, and forskolin are the net stimulation over basal (10 $\mu \mathrm{M}$ GTP). The effects of $\mathrm{Mn}^{2+}$ were assayed in the absence of $\mathrm{Mg}^{2+}$.

nation of ventricular sections stained with hematoxylin and eosin revealed no pathologic abnormalities, particularly myolysis or myocyte necrosis.

Adenylate cyclase activity. Differences in activation of cardiac adenylate cyclase from the three different groups of 29-dold hamsters by various pharmacologic agents suggested that the BIO 14.6 hamster has an abnormality in cardiac signal transduction via $G_{s}$. Basal adenylate cyclase activity with GTP was not significantly different in membranes prepared from ventricles of the BIO 14.6, normal, or $F_{1} M$ animals (Table I). Similarly, adenylate cyclase activity in the presence of $10 \mathrm{mM}$ manganous ion, a direct activator of catalytic adenylate cyclase was not different. The latter finding suggests that the amount of catalytic adenylate cyclase was the same in membrane preparations from all animals. By contrast, adenylate cyclase activity in the presence of either fluoride, forskolin, or isoproterenol was significantly less in cardiac membranes from the BIO 14.6 hamsters than in cardiac membranes from either the normal or $F_{1}$ hybrid animals (Table I). Fluoride stimulates adenylate cyclase by activating $G_{s}(29)$. Forskolin requires $\alpha G_{s}$ and guanine nucleotides to activate adenylate cyclase (30). The diminished effect of isoproterenol probably resulted from altered $G_{s}$ function, as the number and the affinity of cardiac $\beta$-adrenergic receptors (for ICYP) (Table II) were unaltered in the BIO 14.6 hamsters. These results suggest that the hearts from BIO 14.6 animals had altered coupling of $G$ protein effects to catalytic adenylate cyclase. It is not surprising that

Table II. $\beta$-Adrenergic Receptors in Hearts of 29-d-old Normal and Cardiomyopathic Syrian Hamsters

\begin{tabular}{ccc}
\hline Hamsters & Dissociation constant & Maximal ICYP binding \\
\hline$p M$ & fmol/mg protein \\
$\begin{array}{l}\text { Normal }\left(\mathrm{F}_{1} \mathrm{~B}\right) \\
\text { Cardiomyopathic } \\
\text { (BIO 14.6) }\end{array}$ & $43 \pm 12$ & $113 \pm 4$ \\
& $35 \pm 7$ & $100 \pm 9$ \\
\hline
\end{tabular}

Values are mean $\pm \operatorname{SE}(n=4)$. 
adenylate cyclase activity under basal (GTP) conditions in the BIO 14.6 animals was unchanged as similar results have been reported in renal cortex from patients with pseudohypoparathyroidism who have a generalized genetic defect in $\alpha \mathrm{G}_{\mathrm{s}}(31)$. Preliminary studies of cardiac adenylate cyclase in another cardiomyopathic hamster strain (100-d BIO 53.58) yielded similar changes in adenylate cyclase activity (Feldman, A. M., unpublished observations). To investigate further the altered coupling of $\beta$-adrenergic receptors to catalytic adenylate cyclase, we quantified both $\mathrm{G}_{\mathrm{s}}$ and $\mathrm{G}_{\mathrm{i}}$ proteins.

Quantitation of $G_{s}$ activity by cyc complementation. The amount of functional $\alpha \mathrm{G}_{\mathrm{s}}$ activity in hamster tissues was assessed by measuring the ability of detergent extracts of membrane preparations to recouple $\beta$-adrenergic receptors and adenylate cyclase in membranes from cyc ${ }^{-}$S49 murine lymphoma cells. Under the conditions of our assay, there was a direct, linear relation between the amount of cardiac membrane extract added and activation of adenylate cyclase (Fig. 1). This linear relation was found with cardiac extracts from all three groups of hamsters, as well as with extracts from other hamster tissues (data not shown).

Bioactivity of $\alpha \mathrm{G}_{\mathrm{s}}$ in cardiac membranes from BIO 14.6 hamsters was $\simeq 50 \%$ less $(1.1 \pm 0.1$ pmol cAMP per assay tube, $n=5, P<0.01)$ than in normal $F_{1} B$ animals $(2.3 \pm 0.05)$ when measured in the presence of isoproterenol and the nonhydrolyzable GTP analogue Gpp(NH)p. Similarly, in the presence of isoproterenol and the nonhydrolyzable GTP analogue GTP $\gamma$ s, extracts from BIO 14.6 animals were only $50 \%(P$ $<0.01)$ as effective in reconstituting adenylate cyclase activity in $\mathrm{cyc}^{-}$membranes. In some experiments, forskolin was added to the reaction mixture to amplify the activity of the reconstituted system (5). This addition had no effect on the measurement of functional $\alpha \mathrm{G}_{\mathrm{s}}$ as an identical $\simeq 50 \%$ decrease in the activity of $\alpha \mathrm{G}_{\mathrm{s}}$ in the BIO 14.6 hamster was appreciated (Fig. 2). A comparable reduction of $\alpha \mathrm{G}_{\mathrm{s}}$ activity was found in skeletal muscle of the BIO 14.6 animals, whereas $\alpha \mathrm{G}_{\mathrm{s}}$ activity in membranes prepared from either pooled erythrocytes (data not shown), brain, or liver was the same in the three groups. A

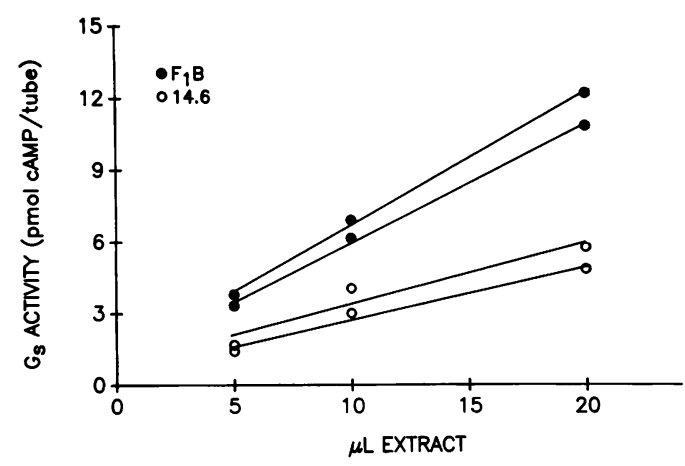

Figure 1. Linear relation between the amount of detergent extract from heart membranes and reconstituted adenylate cyclase activity in cyc ${ }^{-} \mathbf{S} 49$ lymphoma cell membranes. Extracts were prepared from cardiac membranes of $(\bullet)$ normal $F_{1} B$ or $(0)$ cardiomyopathic BIO 14.6 hamsters and mixed with cyc $^{-}$membranes. Adenylate cyclase activity was assessed in the presence of $10 \mu \mathrm{M}$ isoproterenol, $100 \mu \mathrm{M}$ $\mathrm{Gpp}(\mathrm{NH}) \mathrm{p}$, and $10 \mu \mathrm{M}$ forskolin. Points represent the mean of triplicate determinations. Results of two representative experiments are shown.

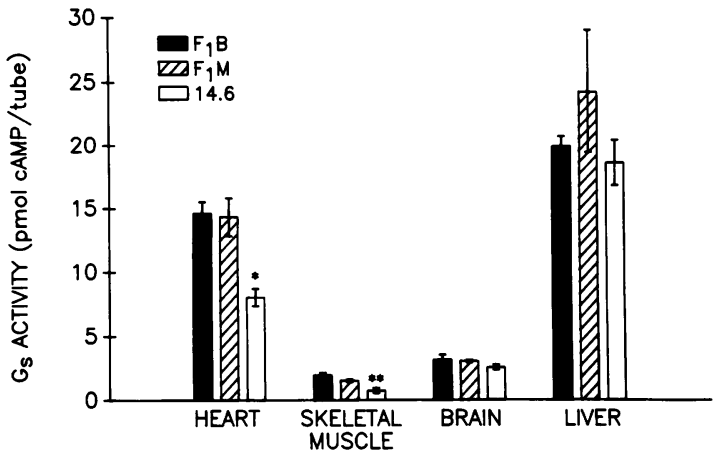

Figure 2. Activity of $\alpha \mathrm{G}_{\mathrm{s}}$ in various tissues from normal $\left(\mathrm{F}_{1} \mathrm{~B}\right)$, heterozygous $\left(F_{1} M\right)$, and cardiomyopathic (14.6) Syrian hamsters as measured by $\mathrm{cyc}^{-}$complementation assay. Assay reactions contained $10 \mu \mathrm{M}$ isoproterenol, $100 \mu \mathrm{M} \mathrm{Gpp}(\mathrm{NH}) \mathrm{p}$, and $10 \mu \mathrm{M}$ forskolin. Results are mean $\pm \operatorname{SEM}(n=5) .{ }^{*} P<0.001,{ }^{* *} P<0.01$.

mixed extract containing equal amounts of cardiac extract from the control $(2.2 \pm 0.4 \mathrm{pmol}$ cAMP per tube, $n=5)$ and BIO $14.6(1.3 \pm 0.4)$ had activity approximately midway (1.6 \pm 0.3$)$ between the activities of either pure extract, suggesting that an inhibitor of adenylate cyclase activation was not present in the BIO 14.6 cardiac membranes. The cyc ${ }^{-}$complementation assays indicate that the coupling defect of cardiac adenylate cyclase in the cardiomyopathic hamster is due to an abnormality in the cardiac $\alpha \mathrm{G}_{\mathrm{s}}$ protein as the coupling defect persisted in $\mathrm{cyc}^{-}$membranes, which contain excess amounts of normal $\beta$-adrenergic receptors, $\alpha \mathrm{G}_{\mathrm{i}}$, and $\beta \gamma$-subunit and normal catalytic adenylate cyclase. In addition, the inability of forskolin and guanine nucleotides to couple the cardiac $\alpha \mathrm{G}_{\mathrm{s}}$ to catalytic adenylate cyclase in the cyc ${ }^{-}$membranes suggests that the bioactivity defect is due to inability of the hamster $\alpha \mathrm{G}_{\mathrm{s}}$ to interact productively with catalytic adenylate cyclase.

Quantitation of $\alpha G_{s}$ by immunochemical analysis. The amount of $\alpha \mathrm{G}_{\mathrm{s}}$ peptide on Western blots prepared from cardiac membranes of 29-d-old control and BIO 14.6 hamsters was assessed using polyclonal antisera directed against a synthetic peptide deduced from the nucleotide sequence of the carboxyl-terminal end of bovine $\alpha \mathrm{G}_{\mathrm{s}}$ (32-34). This antisera was specific for $\alpha \mathrm{G}_{\mathrm{s}}$ as it did not cross-react with other closely related $G$ proteins which migrate on SDS-PAGE to 39,000$41,000 \mathrm{~mol} w \mathrm{w}$. There was a linear relation between the amount of protein applied to the immunoblot and band density on the autoradiographs when $25-100 \mu \mathrm{g}$ of protein was applied (Fig. 3). Alternative splicing of a single gene results in two forms of $\alpha \mathrm{G}_{\mathrm{s}}: 45,000$ and $52,000 \mathrm{~mol} \mathrm{wt}(35,36)$. Although the two $\alpha \mathrm{G}_{\mathrm{s}}$ forms share the same carboxyl-terminal amino acid sequence, the ratio of their concentrations varies in different tissues. We detected only the $45,000 \mathrm{~mol} \mathrm{wt}$ form on immunoblots from hamster cardiac membranes. Considering the amino acid sequence of $\alpha \mathrm{G}_{\mathrm{s}}$ is highly conserved among mammals $(12,13,31,35)$, our finding that antisera directed against the carboxyl terminus of bovine $\alpha \mathrm{G}_{\mathrm{s}}$ cross-reacted readily with hamster $\alpha \mathrm{G}_{\mathrm{s}}$ is not surprising.

In contrast to our finding of different $\alpha \mathrm{G}_{\mathrm{s}}$ bioactivities in cardiac membranes using the cyc $^{-}$complementation assay, levels of immunoreactive $\alpha G_{s}$ were the same in membranes from both groups of hamsters (Fig. 4). 


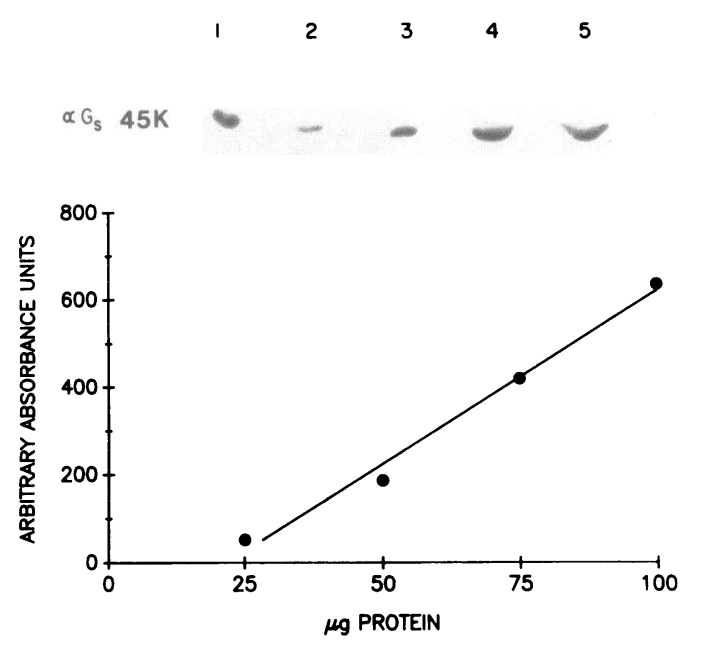

Figure 3. Relation between protein concentration and autoradiographic density on immunoblots. Various amounts $(25-100 \mu \mathrm{g})$ of cardiac membranes were electrophoretically resolved by SDS-PAGE, transferred to PVDF filters, and probed sequentially with rabbit antisera specific for $\alpha \mathrm{G}_{\mathrm{s}}$ and goat anti-rabbit ${ }^{125} \mathrm{I}-\mathrm{F}\left(\mathrm{ab}^{\prime}\right)_{2}$ (lanes 2-5). $K$, molecular weight in thousands. Lane $l$ represents human erythrocyte membranes $(50 \mu \mathrm{g})$. Autoradiographic signal intensity was measured with two-dimensional densitometry and expressed in arbitrary units.

Quantitation of $G$ proteins using bacterial toxin-catalyzed ADP-ribosylation. The bacterial exotoxins from Vibrio cholerae and Bordetella pertussis, which ADP-ribosylate the $\alpha$ subunits of $G_{s}$ and $G_{i} / G_{o}$, respectively, have been used previously to quantify levels of these $G$ proteins in human hearts (5). Because increased levels of cardiac $G_{i}$ can reduce the coupling efficiency of $\beta$-adrenergic receptors to adenylate cyclase by $\mathrm{G}_{\mathrm{s}}(5)$, we measured $\alpha \mathrm{G}_{\mathrm{i}}$ levels in the hearts of the normal and myopathic hamsters. Pertussis toxin catalyzed [ ${ }^{32}$ P]ADPribosylation of one major peptide band $\left(\alpha \mathrm{G}_{40}\right)$. This radiolabeling was time dependent, linear over a range of membrane protein $(10-125 \mu \mathrm{g})$, and reproducible $( \pm 10 \%)$. Under our

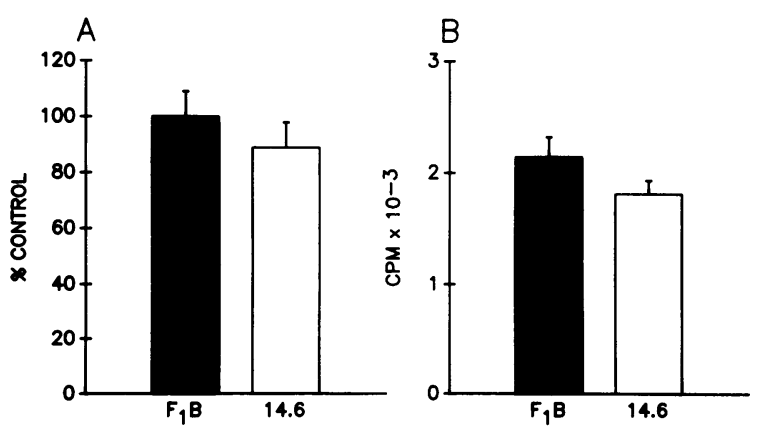

Figure 4. Quantitation of $\alpha \mathrm{G}_{\mathrm{s}}$ by immunoblotting. Membrane proteins from the hearts of normal or cardiomyopathic hamster were electrophoretically resolved and transferred to support filters. After sequential incubation with rabbit antisera specific for $\alpha \mathrm{G}_{\mathrm{s}}$ and goat anti-rabbit ${ }^{125} \mathrm{I}-\mathrm{F}\left(\mathrm{ab}^{\prime}\right)_{2}$, binding of ${ }^{125} \mathrm{I}-\mathrm{F}\left(\mathrm{ab}^{\prime}\right)_{2}$ on the immunoblots was assessed by $(A)$ two-dimensional densitometry of autoradiographs or (B) gamma scintigraphy. Results are $(A)$ the mean \pm SEM ( $n$ $=5$ ) of three separate determinations or $(B)$ the mean $\pm \operatorname{SEM}(n=5)$ of a representative experiment.
A

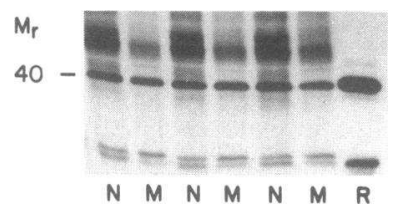

B

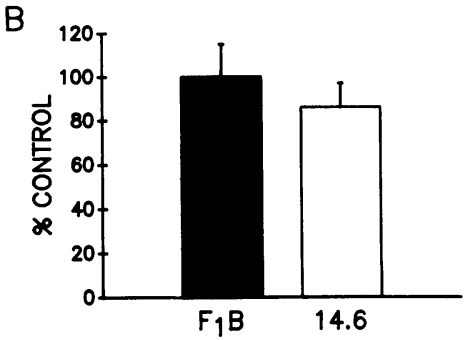

Figure 5. Quantitation of $\alpha \mathrm{G}_{i}$ by pertussis toxin catalyzed ADP-ribosylation. Cardiac membranes were prepared from 29-d-old hamsters and incubated with activated pertussis toxin and $\left[{ }^{32}\right.$ P]NAD. $(A)$ Representative autoradiogram. The radiolabeled products were resolved by SDS-PAGE on a $7.5 \%$ gel. $N, \mathrm{~F}_{1} \mathrm{~B} ; M, \mathrm{BIO} 14.6 ; R$, control human erythrocyte membrane. $M_{\mathrm{r}}, \times 10^{-3} \mathrm{kD}$. (B) $\left[{ }^{32}\right.$ P]ADP-ribosylated pertussis toxin substrate was quantified by two-dimensional densitometry.

Values are expressed as the percentage of the mean of four controls present on each autoradiograph. Values are the mean $\pm \operatorname{SEM}(n=4)$ of four separate experiments.

assay conditions, pertussis toxin ADP-ribosylation was complete as the further addition of [ $\left.{ }^{32} \mathrm{P}\right] \mathrm{NAD}$ and activated toxin did not effect additional incorporation of ${ }^{32} \mathrm{P}$ (results not shown). The amount of ${ }^{32} \mathrm{P}$ incorporated into $\alpha \mathrm{G}_{40}$ of cardiac membranes from the BIO 14.6 hamsters was not significantly different from those of control animals (Fig. 5).

In the presence of pertussis toxin, there was ADP-ribosylation of several proteins with 47,000-58,000 mol wt in membranes prepared from normal animals $\left(F_{1} B\right)$ that were reduced in the membranes from myopathics (Fig. 5). However, two-dimensional densitometry (5) of multiple bands on the Coomassie Blue-stained gels (Fig. 6) did not demonstrate a difference in protein concentrations in the lanes representing normal and myopathic hearts. Furthermore, these 47,000-58,000-mol wt proteins did not bind the antisera utilized to quantitate $\alpha \mathrm{G}_{\mathrm{s}}$

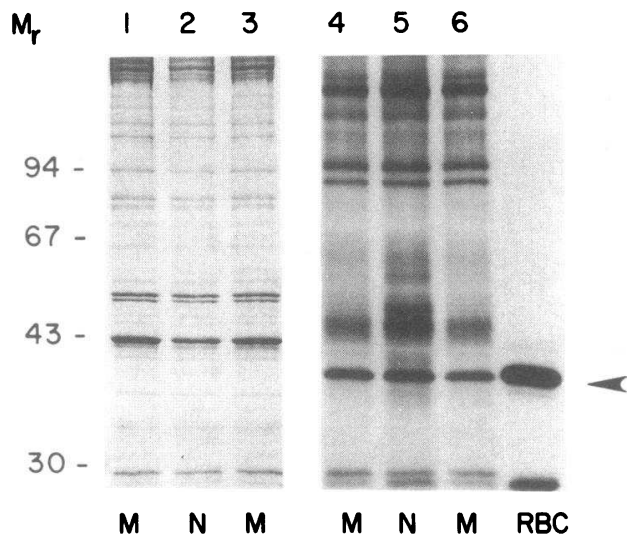

Figure 6. Representative autoradiograph of membranes treated with pertussis toxin. Cardiac membranes from normal $(N)$ or myopathic $(M)$ hamsters were incubated with activated pertussis toxin and $\left.{ }^{32} \mathrm{P}\right] \mathrm{NAD}$ and then resolved by SDS-PAGE on a $7.5 \%$ gel. Lanes 1-3, Coomassie blue-stained gel; lanes 4-6, autoradiograph of the same gel shown in lanes 1-3 with an additional lane containing human erythrocyte membranes radiolabeled with pertussis toxin. Molecular weight markers in thousands shown at left. 
(Fig. 4) or $\alpha \mathrm{G}_{\mathrm{i}}$ (see below). Therefore, although the significance of this disparity is unclear, the levels of $G$ proteins that are substrates for pertussis toxin were the same in cardiac membranes from the normal and myopathic animals.

Despite using reaction conditions for cholera toxin-catalyzed ADP-ribosylation which we have used successfully to ADP-ribosylate $\alpha \mathrm{G}_{\mathrm{s}}$ in membranes from human heart (5), hamster erythrocytes and brain, rabbit heart, and dog heart (Fig. 7), we were unable to effect ADP-ribosylation of $\alpha G_{s}$ by cholera toxin in cardiac membranes from either the control or the BIO 14.6 hamsters. The addition of small amounts of detergent to the reaction mixture, which has been used to allow pertussis toxin-mediated ADP-ribosylation of $\mathrm{G}$ proteins in sperm membranes (37), did not alter our inability to effect ADP-ribosylation. It is unlikely that this disparity is due to absence of ADP-ribosylation factor (38) in the hamster cardiac membranes, as the addition of crude ADP-ribosylation factor present in cyc ${ }^{-}$S49 cell membranes did not affect the results. The reasons for our inability to ADP-ribosylate $\alpha \mathrm{G}_{\mathrm{s}}$ in hamster heart with cholera toxin remain unclear. This inability to adequately ADP-ribosylate $\alpha \mathrm{G}_{\mathbf{s}}$ in the presence of cholera toxin has been found in another laboratory (Bilezikian, J. P., personal communication).

Quantitation of $\alpha G_{i}$ by immunochemical analysis. To confirm the results of the pertussis toxin-catalyzed ADP-ribosylation, we also measured the relative amounts of $\alpha G_{i}$ on Western blots prepared from cardiac membranes using an affinity-purified antibody from polyclonal antiserum raised using a synthetic peptide identical to a portion of the amino acid sequence of mouse $\alpha \mathrm{G}_{\mathrm{i}}$ (12). In cardiac membranes, this affinity-purified antibody detected a 38,000-mol wt protein which comigrated with a protein detected by this same antibody in a preparation of partially purified $G$ protein from bovine brain. In addition, the protein detected by the $\alpha \mathrm{G}_{\mathrm{i}}$ antibody comigrated with a protein recognized by a polyclonal antiserum raised to a 10-amino acid synthetic peptide corresponding to a region of rat $\alpha \mathrm{G}_{\mathrm{i}}$ common to $\alpha \mathrm{G}_{\mathrm{i}}-1$ and $\alpha \mathrm{G}_{\mathrm{i}}-3$ (Feldman, A. M., and $\mathrm{C}$. Van Dop, unpublished observations). Furthermore, there was a linear relation between the amount of membrane protein applied to the immunoblot and ${ }^{125}$ I bound on the Western blot (Fig. 8). The relative amount of immunodetectable $\alpha G_{i}$ in cardiac membranes from BIO 14.6 animals was the same as
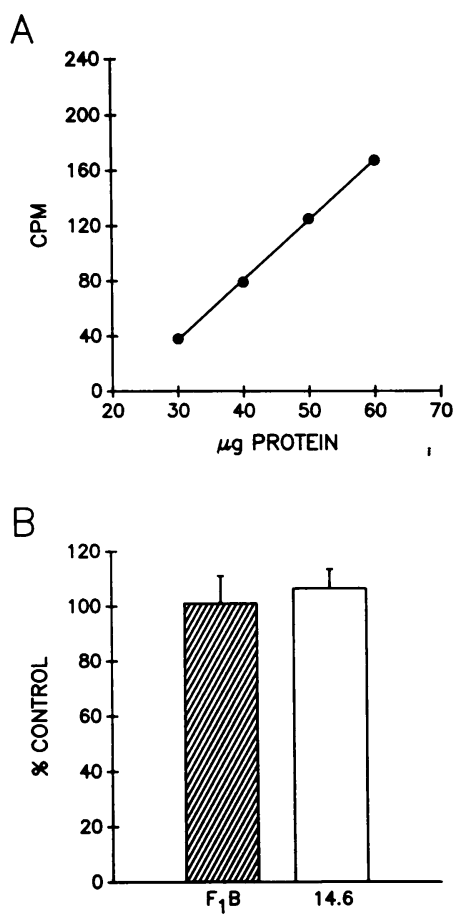

Figure 8. Quantitation of $\alpha \mathrm{G}_{\mathrm{i}}$ by immunoblotting. $(A)$ Linear relation between protein concentration and ${ }^{125} \mathrm{I}$ binding at a 40,000 mol wt protein. Varying amounts of hamster cardiac membranes were electrophoretically resolved by SDS-PAGE, transferred to PVDF filters, and probed sequentially with anti- $\alpha G_{i}$ rabbit antisera and goat anti-rabbit ${ }^{125} \mathrm{I}-\mathrm{F}\left(\mathrm{ab}^{\prime}\right)_{2}$. Autoradiography was performed and regions of the blots that corresponded to bands on the autoradiograms were excised. The amount of radioactivity was quantified using a gamma-counter. (B) Membranes $(40 \mu \mathrm{g})$ from either normal $\left(F_{1} B\right)$ or myopathic (BIO 14.6) hamsters were subjected to SDS-PAGE and immunoblotting as described. The results are the mean $\pm \operatorname{SEM}(n=5$ animals) of three separate experiments.

that in the normal $F_{1} B$ animals (Fig. 8). These results with the affinity-purified antibody confirmed the data obtained with pertussis toxin-catalyzed ADP-ribosylation.

Northern blot and dot blot analysis. Under the high-stringency conditions used, Northern blot analysis revealed a single RNA band $(1.8 \mathrm{~kb})$ on blots of size-fractionated RNA prepared from hearts of both control and BIO 14.6 hamsters (Fig. 9). Using cDNA encoding the $\alpha$-subunit of G protein from a different mammalian species to probe RNA blots diminishes cross-hybridization of the probe to RNA encoding homologous $\mathbf{G}$ proteins (Levine, M. A., personal communication). Dot blots prepared using cardiac RNA from control and BIO 14.6 animals and probed with radiolabeled $\alpha \mathrm{G}_{\mathrm{s}} \mathrm{cDNA}$ re-
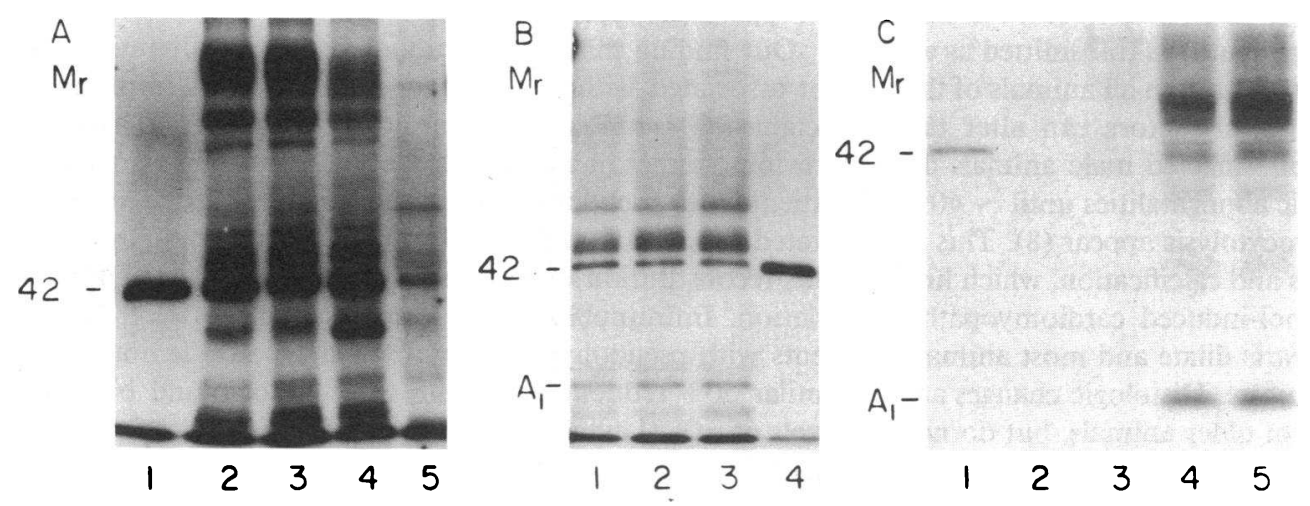

Figure 7. Autoradiograph of membranes treated with cholera toxin. Membranes prepared from tissues of 29-d-old hamsters were incubated with activated cholera toxin and [ $\left.{ }^{32} \mathrm{P}\right]$ NAD before fractionation using SDS-PAGE in a $7.5 \%$ gel. Molecular weight marker in thousands shown at left in each panel. Individual lanes contained $75 \mu \mathrm{g}$ of membranes prepared from: $A 1$, human erythrocytes; $A 2, \mathrm{~F}_{1} \mathrm{~B}$ erythrocytes; $A 3$, $\mathrm{F}_{1}$ B erythrocytes; $A 4$, BIO 14.6

erythrocytes; $A 5$, rabbit heart; $B 1, \mathrm{~F}_{1} \mathrm{~B}$ brain; $B 2, \mathrm{~F}_{1} \mathrm{M}$ brain; $B 3$, BIO 14.6 brain; $B 4$, human erythrocytes; $C 1$, human erythrocytes; $C 2$, human erythrocytes without cholera toxin addition; $C 3$, cyc $^{-} S 49$ lymphoma membranes (which lack $\alpha \mathrm{G}_{\mathrm{s}}$ ); $C 4, \mathrm{~F}_{1} \mathrm{~B}$ heart without cholera toxin addition; $C 5, \mathrm{~F}_{1} \mathrm{~B}$ heart. $A_{1}$ indicates the ADP-ribosylated cholera toxin subunit. 

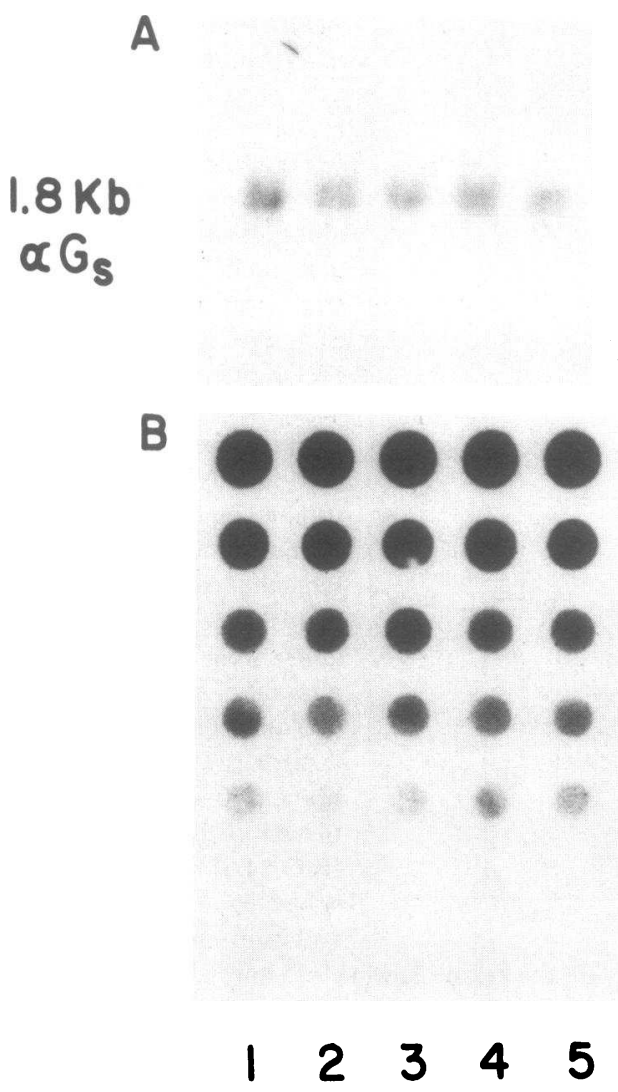

Figure 9. mRNA encoding $\alpha G_{s}$ in hearts from $F_{1} B$ and BIO 14.6 hamsters. $(A)$ Northern blot of size fractionated total RNA $(10 \mu \mathrm{g})$ from hearts of $F_{1} B$ hamsters (lanes 1,3 , and 5) or hearts of BIO 14.6 hamsters (lanes 2 and 4 ). (B) Representative dot blot probed under high-stringency conditions.

vealed no significant difference in mRNA levels encoding $\alpha \mathrm{G}_{\mathrm{s}}$ $\left(\mathrm{F}_{1} \mathrm{~B}, 103 \pm 8 \%\right.$ of control; BIO $\left.14.6,93 \pm 8 \%, n=11\right)$.

\section{Discussion}

The cardiomyopathic Syrian hamster (BIO 14.6) has been widely studied as an animal model for congestive heart failure in humans (39); however, the biochemical alterations responsible for development of cardiac failure remain controversial. The development of this cardiomyopathy is transmitted as an autosomal recessive trait and is expressed in all animals of the affected strains although nutritional factors can alter the course of the disease. Hearts from affected male animals do not demonstrate light microscopic abnormalities until $\sim 40 \mathrm{~d}$ of age when multiple foci of myocytolysis appear (8). This is followed by healing with sclerosis and calcification, which histologically resembles isoproterenol-induced cardiomyopathy in the rat (40). Inevitably, the hearts dilate and most animals die with frank congestive heart failure. Histologic changes are also observed in skeletal muscle of older animals, but do not lead to extreme muscle atrophy and contractures. Numerous biochemical changes have been described in hearts from this cardiomyopathic hamster. Most of these changes are detected only in the late stages of the disease $(10,41,42)$. However, young animals have abnormally increased myocardial calcium accumulation with acute isoproterenol injection (43) and elevated cardiac calcium levels (44). Of particular interest is the fact that chronic treatment of animals before the onset of myocytolysis with either isoproterenol (44) or verapamil (45, 46) delays development of the cardiac abnormalities. In summary, the cardiomyopathic state can be attenuated by treatment with either adrenergic agonists or calcium channel blockers suggesting the presence of abnormalities in the metabolic pathways that regulate both calcium metabolism and adenylate cyclase activity.

We have demonstrated in the cardiomyopathic Syrian hamster (BIO 14.6) a functional abnormality of cardiac adenylate cyclase that results from a qualitative defect in $G_{s}$ protein. This abnormality of $G_{s}$ is specific to cardiac and skeletal muscle, occurs only in animals homozygous for the dystrophic trait, and is present before development of characteristic light microscopic abnormalities. It is unlikely that the inability of detergent extracts from the BIO 14.6 animals to reconstitute adenylate cyclase activity in the $\mathrm{cyc}^{-}$membranes could be due to a change in the activity of either $\alpha \mathrm{G}_{\mathrm{i}}$ or free $\beta \gamma$-subunits as the cyc ${ }^{-}$membrane contains an excess of both and the assay is therefore insensitive to changes in the levels of these peptides (5). The functional decrease in $\alpha \mathrm{G}_{\mathrm{s}}$ was not associated with altered levels of either immunoreactive $\alpha \mathrm{G}_{\mathrm{s}}$ or mRNA encoding $\alpha \mathrm{G}_{\mathrm{s}}$. Thus, it represents a qualitative rather than a quantitative defect. The functional alteration diminishes coupling of $\beta$-adrenergic receptors to adenylate cyclase and thereby may contribute to the development of the abnormal mechanical performance previously reported in these animals (47).

The recent demonstration $(48,49)$ that $\alpha \mathrm{G}_{\mathrm{s}}$ can directly activate the slow, voltage-gated calcium channel in both cardiac and skeletal muscle independent of protein kinase-mediated phosphorylation suggests that altered bioactivity of $\alpha \mathrm{G}_{8}$ in the hearts of cardiomyopathic hamsters may contribute to the contractile abnormality. If activated $\alpha \mathrm{G}_{\mathrm{s}}$ normally modulates calcium channels in muscle without normally increasing intracellular cAMP, disposal of cytoplasmic calcium will be abnormal. To survive, the cells would then need to sequester this increased intracellular calcium into subcellular organelles resulting ultimately in the classical pathologic abnormality seen in these animals. This hypothesis is supported by in vivo studies in 30-d-old myopathic hamsters which demonstrated an enhanced accumulation of $\mathrm{Ca}^{2+}$ after acute injection of isoproterenol $(43,50)$. However, further studies will be needed to support this theory.

Our finding that the functional $G$ protein alteration was not associated with a quantitative difference in immunodetectable $\alpha \mathrm{G}_{\mathrm{s}}$ is unique to the cardiomyopathic Syrian hamster. Previous studies in a canine model of heart failure (6) and in patients with pseudohypoparathyroidism type Ia (51) demonstrated functional alterations in $\alpha \mathrm{G}_{\mathrm{s}}$ as measured by either $\mathrm{cyc}^{-}$reconstitution or by cholera toxin-catalyzed ADP-ribosylation. Immunoblotting studies in erythrocytes from patients with pseudohypoparathyroidism type Ia demonstrated similar $50 \%$ reductions of both immunologic and bioactive levels of $\alpha \mathrm{G}_{\mathrm{s}}$ (Levine, M. A., personal communication). The heritable diminution of $\alpha \mathrm{G}_{\mathrm{s}}$ that occurs in pseudohypoparathyroidism type Ia affects all tissues and has not been reported to be associated with cardiomyopathy. Therefore, our demonstration that diminished $\alpha \mathrm{G}_{\mathrm{s}}$ bioactivity is specific to cardiac and skeletal muscle suggests that the defect is related to the 
genetic lesion in cardiomyopathic hamsters that affects only these two tissues.

It is unlikely that a generalized loss in membrane components, inflammatory or fibrotic changes, or decreased protein yield accounts for the changes demonstrated in the present study. There was no evidence of a pathologic abnormality in the 29-d-old hamsters; heart weights were equivalent in the normal and myopathic animals; and membrane markers including $\beta$-receptor number and levels of the $40,000-\mathrm{mol} \mathrm{wt}$ pertussis toxin $G$ protein substrate were not significantly altered in the BIO 14.6 animals when compared with controls.

Since the promoter region of the $\alpha \mathrm{G}_{\mathrm{s}}$ gene lacks a typical TATA box or CAAT box and has multiple transcriptional initiation sites (52), control of expression of the $\alpha \mathrm{G}_{\mathrm{s}}$ gene is probably the same as other housekeeping genes: at the level of transcription. Therefore, the finding that steady-state levels of the message encoding $\alpha \mathrm{G}_{\mathrm{s}}$ were not changed in the cardiomyopathic hamster supports the finding that $\alpha \mathrm{G}_{\mathrm{s}}$ protein concentration is not altered. The alteration in functional activity of the $\alpha \mathrm{G}_{\mathrm{s}}$ peptide likely results from either an alteration in the primary structure of the peptide or a difference in posttranslational modification. As the animals heterozygous for the cardiomyopathic trait did not demonstrate altered $\mathrm{G}_{\mathrm{s}}$ activity, it is unlikely that a point mutation in the $\alpha \mathrm{G}_{\mathrm{s}}$ gene accounts for our results. Alternate processing of the $\alpha \mathrm{G}_{\mathrm{s}}$ transcript has been demonstrated (36); however, the functional significance of the resulting slight differences in amino acid sequence remains unclear (2). Cholera toxin can posttranslationally modify $\alpha \mathrm{G}_{\mathrm{s}}$ activity by catalyzing the covalent addition of an ADP-ribose moiety to a specific arginine residue (53) on $\alpha \mathrm{G}_{\mathrm{s}}$ (12). Additionally, cellular ADP-ribosyltransferases specific for arginine residues have been identified in eukaryotes (54), and crude cardiac membranes contain an apparently enzymatic, NADdependent activity that enhances adenylate cyclase and is inhibited by coincubation with arginine (55). We therefore postulate that a heritable loss of an enzyme or protein required for tissue-specific processing of transcripts or for covalent posttranslational modulation of $\alpha \mathrm{G}_{\mathrm{s}}$ activity in muscle tissue may explain our findings in the cardiomyopathic hamster. The presence of several pertussis toxin substrates which are present in cardiac membranes of myopathic animals at considerably lower concentrations then in membranes from normal hamsters may provide clues to the identity of this protein.

In summary, we have demonstrated a functional defect in $\alpha \mathrm{G}_{\mathrm{s}}$ of cardiac and skeletal muscle in the cardiomyopathic Syrian hamster (BIO 14.6). This defect is demonstrable before pathologic abnormalities develop in the heart and is not associated with a change in immunochemically detectable $\alpha \mathrm{G}_{\mathrm{s}}$.

\section{Acknowledgments}

We thank Dr. Janet Robishaw for generously providing $\alpha \mathrm{G}_{\mathrm{s}}$ antisera, Dr. Henry R. Bourne for his gift of $\alpha \mathrm{G}_{\mathrm{i}}$ antibody, Dr. Richard R. Neubig for generously supplying partially purified $\alpha \mathrm{G}$, Dr. Randall R. Reed for providing the $\alpha \mathrm{G}_{\mathrm{s}}$ cDNA, and Marsha D. Jackson and Rowena $\mathrm{G}$. Tena for their assistance in performing the immunoblotting. We also appreciate the helpful advice of Dr. Cornelis Van Dongen (Biobreeders, Inc., Fitchburg, MA).

This work was supported in part by National Institutes of Health Institutional Training Research Grant T32 HL-07227 (Dr. Kessler), grant DK-36085 (Dr. Van Dop); National Institutes of Health grant HL-39719, an institutional research grant from the Johns Hopkins
Medical Institutions, a grant-in-aid from the American Heart Association, Maryland Affiliate, and the Otsuka Pharmaceutical Company (Dr. Feldman). In addition, Dr. Van Dop is supported by a Basil O'Connor Research Starter Grant from the March of Dimes and Dr. Feldman is the recipient of a Clinician Scientist Career Development Award from the Andrew W. Mellon Foundation.

\section{References}

1. Stryer, L., and H. R. Bourne. 1986. G proteins: a family of signal transducers. Annu. Rev. Cell. Biol. 2:391-419.

2. Gilman, A. G. 1987. G proteins: transducers of receptor-generated signals. Annu. Rev. Biochem. 56:615-649.

3. Epstein, S. E., C. L. Skelton, G. S. Levey, and M. Entman. 1970. Adenyl cyclase and myocardial contractility. Ann. Intern. Med. 72:561-578.

4. Drummond, G. E., and D. L. Severson. 1979. Cyclic nucleotides and cardiac function. Circ. Res. 44:145-152.

5. Feldman, A. M., A. E. Cates, W. B. Veazey, R. E. Hershberger, M. R. Bristow, K. L. Baughman, W. A. Baumgartner, and C. Van Dop. 1988. Increase of the 40,000 -mol wt pertussis toxin substrate (G protein) in the failing human heart. J. Clin. Invest. 82:189-197.

6. Longabaugh, J. P., D. E. Vatner, S. F. Vatner, and C. J. Homcy. 1988. Decreased stimulatory guanosine triphosphate binding protein in dogs with pressure-overload left ventricular failure. J. Clin. Invest. 81:420-424.

7. Bajusz, E. 1969. Hereditary cardiomyopathy: a new disease model. Am. Heart J. 77:686-696.

8. Strobeck, J. E., S. M. Factor, A. Bhan, M. Sole, C. C. Liew, F. Fein, and E. H. Sonnenblick. 1979. Hereditary and acquired cardiomyopathies in experimental animals: mechanical, biochemical, and structural features. Ann. NY Acad. Sci. 317:59-88.

9. Wagner, J. A., I. J. Reynolds, H. F. Weisman, P. Dudeck, M. L. Weisfeldt, and S. H. Snyder. 1986. Calcium antagonist receptors in cardiomypathic hamster: selective increases in heart, muscle, brain. Science (Wash. DC). 232:515-518.

10. Whitmer, J. T., P. Kumar, and R. J. Solaro. 1988. Calcium transport properties of cardiac sarcoplasmic reticulum from cardiomyopathic Syrian hamsters (BIO 53.58 and 14.6): evidence for a quantitative defect in dilated myopathic hearts not evident in hypertrophic hearts. Circ. Res. 62:81-85.

11. Franch, H. A., R. A. F. Dixon, E. H. Blain, and P. K. Siegl. 1987. Ventricular atrial natriuretic factor in the cardiomyopathic hamster model of congestive heart failure. Circ. Res. 62:31-36.

12. Sullivan, K. A., Y.-C. Liao, A. Alborzi, B. Beiderman, F.-H. Chang, S. B. Masters, A. D. Levinson, and H. R. Bourne. 1986. Inhibitory and stimulatory $\mathrm{G}$ proteins of adenylate cyclase: cDNA and amino acid sequences of the $\alpha$ chains. Proc. Natl. Acad. Sci. USA. 83:6687-6691.

13. Jones, D. T., and R. R. Reed. 1987. Molecular cloning of five GTP-binding protein cDNA species from rat olfactory neuroepithelium. J. Biol. Chem. 262:14241-14249.

14. Van Vleet, J. F., and V. J. Ferrans. 1986. Myocardial diseases of animals. Am. J. Pathol. 124:98-178.

15. Lowry, O. H., N. J. Rosebrough, A. L. Farr, and R. J. Randall. 1951. Protein measurements with the folin phenol reagent. J. Biol. Chem. 193:265-275.

16. Bristow, M. R., R. Ginsburg, W. Minobe, R. S. Cubicciotti, W. S. Sageman, K. Lurie, M. E. Billingham, D. C. Harrison, and E. B. Stinson. 1982. Decreased catecholamine sensitivity and $\beta$-adrenergic receptor density in failing human hearts. N. Engl. J. Med. 307:205211.

17. Kaslow, H. R., G. L. Johnson, V. M. Brothers, and H. R. Bourne. 1980. A regulatory component of adenylate cyclase from human erythrocyte membranes. J. Biol. Chem. 255:3736-3741.

18. Worley, P. F., J. M. Baraban, C. Van Dop, E. J. Neer, and S. H. Snyder. 1986. Proc. Natl. Acad. Sci. USA. 83:4561-4565. 
19. Feldman, A. M., M. A. Levine, G. Gerstenblith, K. D. Kaufman, and K. L. Baughman. 1987. Negative inotropic effects of furosemide in the isolated rabbit heart: a prostaglandin-mediated event. $J$. Cardiovasc. Pharmacol. 9:493-499.

20. Salomon, Y. 1979. Adenylate cyclase assay. Adv. Cyclic Nucleotide Res. 10:35-55.

21. Bourne, H. R., P. Coffino, and G. M. Tomkins. 1975. Selection of a variant lymphoma cell deficient in adenylate cyclase. Science (Wash. DC). 187:750-752.

22. Johnson, G. L., and H. R. Bourne. 1977. Influence of cholera toxin on the regulation of adenylate cyclase by GTP. Biochem. Biophys. Res. Commun. 78:792-798.

23. Laemmli, U. K. 1970. Cleavage of structural proteins during the assembly of the head of bacteriophage T4. Nature (Lond.). 227:680-685.

24. Feldman, A. M., A. E. Cates, M. R. Bristow, and C. Van Dop. Altered expression of $\alpha$-subunits of $\mathrm{G}$ proteins in failing human hearts. J. Mol. Cell. Cardiol. In press.

25. Feinberg, A. P., and B. Vogelstein. 1984. A technique for radiolabeling DNA restriction endonuclease fragments to high specific activity: Addendum. Anal. Biochem. 137:266-267.

26. Bristow, M. R., R. Ginsburg, A. Strosberg, W. Montgomery, and W. Minobe. 1984. Pharmacology and inotropic potential of forskolin in the human heart. J. Clin. Invest. 74:212-223.

27. Bristow, M. R., R. Ginsburg, V. Ulmans, M. Fowler, W. Minobe, R. Rasmussen, P. Zera, R. Menlove, P. Shah, S. Jamieson, and E. B. Stinson. 1986. $\beta_{1}$ - and $\beta_{2}$-Adrenergic-receptor subpopulations in no failing and failing human ventricular myocardium: coupling of both receptor subtypes to muscle contraction and selective $\beta_{1}$-receptor down-regulation in heart failure. Circ. Res. 59:297-309.

28. Wallenstein, S., C. L. Zucker, and J. L. Fleiss. 1980. Some statistical methods useful in circulation research. Circ. Res. 47:1-9.

29. Sternweis, P. C., and A. G. Gilman. 1982. Aluminum: a requirement for the activation of the regulatory component of adenylate cyclase by fluoride. Proc. Natl. Acad. Sci. USA. 79:4888-4891.

30. Hildebrandt, J. D., J. Hanoune, and L. Birnbaumer. 1982. Guanine nucleotide inhibition of $\mathrm{cyc}^{-} \mathrm{S} 49$ mouse lymphoma cell membrane adenylyl cyclase. J. Biol. Chem. 257:14723-14725.

31. Drezner, M. K., and W. M. Burch. 1978. Altered activity of the nucleotide regulatory site in the parathyroid hormone-sensitive adenylate cyclase from the renal cortex of a patient with pseudohypoparathyroidism. J. Clin. Invest. 62:1222-1227.

32. Robishaw, J. D., D. W. Russell, B. A. Harris, M. D. Smigel, and A. G. Gilman. 1986. Deduced primary structure of the $\alpha$ subunit of the GTP-binding protein of adenylate cyclase. Proc. Natl. Acad. Sci. USA 83:1251-1255.

33. Mumby, S. M., R. A. Kahn, D. R. Manning, and A. G. Gilman. 1986. Antisera of designed specificity for subunits of guanine nucleotide-binding regulatory proteins. Proc. Natl. Acad. Sci. USA. 83:265269.

34. Mumby, S., I. H. Pang, A. G. Gilman, and P. C. Sternweis. 1988. Chromatographic resolution and immunologic identification of the $\alpha_{40}$ and $\alpha_{41}$ subunits of guanine nucleotide-binding regulatory proteins from bovine brain. J. Biol. Chem. 263:2020-2026.

35. Robishaw, J. D., M. D. Smigel, and A. G. Gilman. 1986. Molecular basis for two forms of the $G$ protein that stimulates adenylate cyclase. J. Biol. Chem. 261:9587-9590.

36. Bray, P., A. Carter, C. Simons, V. Guo, C. Puckett, J. Kamholz, A. Spiegel, and M. Nirenberg. 1986. Human cDNA clones for four species of $\mathrm{G} \alpha_{\mathrm{s}}$ signal transduction protein. Proc. Natl. Acad. Sci. USA. 83:8893-8897.

37. Bentley, J. K., D. L. Garbers, S. E. Domino, T. D. Noland, and C. Van Dop. 1986. Spermatozoa contain a guanine nucleotide-binding protein ADP-ribosylated by pertussis toxin. Biochem. Biophys. Res. Commun. 138:728-734.
38. Kahn, R. A., and A. G. Gilman. 1984. Purification of a protein cofactor required for ADP-ribosylation of the stimulatory regulatory component of adenylate cyclase by cholera toxin. J. Biol. Chem. 259:6228-6234.

39. Homburger, F. 1979. Myopathy of hamster dystrophy: history and morphologic aspects. Ann. NY Acad. Sci. 317:2-17.

40. Reichenbach, D. D., and E. P. Benditt. 1968. Myofibrillar degeneration. A response of the myocardial cell to injury. Arch. Pathol. 85:189-199.

41. Malhotra, A., M. Karell, and J. Scheuer. 1985. Multiple cardiac contractile protein abnormalities in myopathic Syrian hamsters (Bio 53.58). J. Mol. Cell. Cardiol. 17:95-107.

42. Hoppel, C. L., B. Tandler, W. Parland, J. S. Turkaly, and L. D. Albers. 1982. Hamster cardiomyopathy: a defect in oxidative phosphorylation in the cardiac interfibrillar mitochondria. J. Biol. Chem. 257:1540-1548.

43. Lossnitzer, K., W. Mohr, A. Konrad, and R. Guggenmoos. 1978. Hereditary cardiomyopathy in the Syrian golden hamster: influence of verapamil as a calcium antagonist. In Cardiomyopathy and Myocardial Biopsy. M. Kaltenbach, F. Loggen, and E. G. J. Olsen, editors. Springer-Verlag, Inc., New York. 27-37.

44. Jasmin, G., and L. Proschek. 1983. Paradoxical effect of isoproterenol on hamster hereditary polymyopathy. Muscle Nerve. 6:408-415.

45. Rouleau, J.-L., L. H. S. Chuck, G. Hollosi, P. Kidd, R. E. Sievers, J. Wikman-Coffelt, and W. W. Parmley. 1982. Verapamil preserves myocardial contractility in the hereditary cardiomyopathy of the Syrian hamster. Circ. Res. 50:405-412.

46. Jasmin, G., and B. Solymoss. 1975. Prevention of hereditary cardiomyopathy in the hamster by verapamil and other agents. Proc. Soc. Exp. Biol. Med. 149:193-198.

47. Brink, A. J., and A. Lochner. 1967. Work performance of the isolated perfused beating heart in the hereditary myocardiopathy of the Syrian hamster. Circ. Res. 21:391-401.

48. Yatani, A., J. Codina, Y. Imoto, J. P. Reeves, L. Birnbaumer, and A. M. Brown. 1987. A G protein directly regulates mammalian cardiac calcium channels. Science (Wash. DC). 238:1288-1292.

49. Yatani, A., Y. Imoto, J. Codina, S. L. Hamilton, A. M. Brown, and $L$. Birnbaumer. 1988. The stimulatory $G$ protein of adenylyl cyclase, $G_{s}$, also stimulates dihydropyridine-sensitive $\mathrm{Ca}^{2+}$ channels: evidence for direct regulation independent of phosphorylation by c-AMP dependent protein kinase or stimulation by a dihydropyridine agonist. J. Biol. Chem. 263:9887-9895.

50. Lossnitzer, K., J. Janke, B. Hein, M. Stauch, and A. Fleckenstein. 1975. Disturbed myocardial calcium metabolism: A possible pathogenetic factor in the hereditary cardiomyopathy of the Syrian hamster. In Recent Advances in Studies on Cardiac Structure and Metabolism. A. Fleckenstein and G. Rona, editors. University Park Press, Baltimore. 207-217.

51. Van Dop, C., and H. R. Bourne. 1983. Pseudohypoparathyroidism. Annu. Rev. Med. 34:259-266.

52. Kozasa, T., H. Itoh, T. Tsukamoto, and Y. Kaziro. 1988. Isolation and characterization of the human $\mathrm{G}_{\mathrm{s}}$ alpha gene. Proc. Natl. Acad. Sci. USA. 85:2081-2085.

53. Van Dop, C., M. Tsubokawa, H. R. Bourne, and J. Ramachandran. 1984. Amino acid sequence of retinal transducin at the site ADP-ribosylated by cholera toxin. J. Biol. Chem. 259:696-698.

54. Moss, J., and M. Vaughan. 1978. Isolation of an avian erythrocyte protein possessing ADP-ribosyltransferase activity and capable of activating adenylate cyclase. Proc. Natl. Acad. Sci. USA. 75:36213624.

55. Feldman, A. M., M. A. Levine, K. L. Baughman, and C. Van Dop. 1987. NAD ${ }^{+}$-mediated stimulation of adenylate cyclase in cardiac membranes. Biochem. Biophys. Res. Commun. 142:631-637. 